\title{
Compulsory Dispute Settlement Entailing Binding Decisions under the UNCLOS: Its Applicability to the Case of Vietnam
}

\author{
Ngo Huu Phuoc*
}

Hybrid dispute settlement mechanism is one of the characteristics of the UNCLOS. It is the combination of diplomatic measures and judicial proceedings. Among them, the ITLOS established in accordance with Annex VI, and two types of arbitral tribunal constituted in accordance with Annexes VII and VIII are means for the disputes settlement firstly regulated in the UNCLOS. Especially, according to Article 287, an arbitral tribunal constituted under Annex VII has default jurisdiction in case one or both parties to a dispute are not covered by a declaration in force, or the parties to a dispute have not accepted the same procedure for the settlement of the dispute. These means of dispute settlement have supplemented and enhanced the source of law for international dispute resolution more diversified. This paper clarifies some aspects of compulsory procedures entailing binding decisions under the UNCLOS, evaluates the applicability of these procedures to the case of Vietnam in the disputes settlement on interpretation or application of the UNCLOS raising among countries in the South China Sea.

\section{Keywords}

UNCLOS, Dispute Settlement, ICJ, ITLOS, Arbitration, Vietnam

* Lecturer at University of Economics and Law, Vietnam; Lecturer at Vietnam National University Ho Chi Minh City, Vietnam. LL.B./LL.M./Ph.D. (Ho Chi Minh City U. of Law). ORCID: http://orcid.org/0000-0002-8189-7600. The author may be contacted at: phuocnh@uel.edu.vn/Address: Faculty of Economic Law, VNUHCM-University of Economics and Law, Quarter 3, Linh Xuan Ward, Thu Duc City, Ho Chi Minh City 700000, Vietnam. All the websites in this article were last visited on April 28, 2021. 


\section{Overview}

The United Nations Convention on the Law of the Sea (UNCLOS) was opened for signature at Montego Bay, Jamaica, on December 10, 1982 and entered into force on November 16, 1994. ${ }^{1}$ The UNCLOS, which comprises 320 articles and nine annexes, is the most significant international legal instrument for coastal states in establishing and exercising the sovereignty and jurisdiction over the sea as well as developing and managing ocean resources for peaceful purposes. One of the most influential features of the UNCLOS is its dispute settlement system reserving 26 articles (Articles 186-190 and Articles 279 -299) and four annexes ${ }^{2}$ that consist of 74 articles to identify mechanism and procedures governing the disputes settlement. Especially, the UNCLOS, with the provisions of Part XV and four annexes on the settlement of dispute, has set up a separate, completely new, and highly feasible dispute settlement system that countries can apply to resolve disputes on the interpretation or application of the UNCLOS.

The dispute settlement mechanism under the UNCLOS includes: (1) political and diplomatic measures such as negotiation, investigation, mediation, conciliation; (2) regional agreements; ${ }^{3}$ (3) judicial proceedings including the International Court of Justice (ICJ) ${ }^{4}$ and the International Tribunal for the Law of the Sea (ITLOS); (4) an arbitral tribunal constituted under Annex VII (hereinafter arbitration); and (5) a special arbitral tribunal constituted in accordance with Annex VIII.

The dispute settlement system under the UNCLOS is unique because of the

1 Under Article 308 of UNCLOS, the Convention entered into force 12 months after the date of deposit of the 60th instrument of ratification or accession. Vietnam ratified the UNCLOS on June 23, 1994, and deposited it at the UN on July $25,1994$.

2 The four annexes include: Annex V on Conciliation; Annex VI on the Statute of the International Tribunal for the Law of the Sea; Annex VII on Arbitration; and Annex VIII on Special Arbitration.

3 U.N. Charter art. 33, 11.

4 The ICJ has jurisdiction to settle disputes concerning the interpretation and application of UNCLOS if the ICJ is given jurisdiction by the parties to the dispute on the basis of special agreement or an international treaty pursuant to Article 36, paragraph 1 of the ICJ Statute or the provision on the dispute settlement mechanism in international treaties, including the UNCLOS such as Article 287, paragraph 1, subparagraph (b). Moreover, the ICJ still has jurisdiction through a mandatory ICJ procedure as provided for in Article 36, paragraph 2 that allows states to make a statement of acceptance of the ICJ in respect of a dispute or related to disputes in certain fields. As of October 2020, there were 74 statements that cover the choice of the ICJ, and among them, there are many statements concerning the settlement of maritime disputes. However, a small number of statements exclude the ICJ's jurisdiction in respect to some issues, such as the Australian Declaration in 2002 that excluded disputes over maritime boundary delimitation, the Canadian Declaration in 2004 that excluded disputes concerning fisheries, and the New Zealand Declaration in 1977 that excluded disputes related to exclusive economic zone. See Declarations recognizing the jurisdiction of the Court as compulsory, https://www.icj-cij.org/en/declarations. 
following elements: First, traditional dispute settlement measures such as negotiation, investigation, mediation, conciliation and regional arrangements are combined with new ones, including ITLOS, arbitral tribunals, and special arbitral tribunals. Second, arbitration shall be set up as the default dispute settlement procedure in case either a party or both parties of the dispute have not issued a statement regarding their choice of dispute settlement procedure, or the parties have not accepted the same procedure for the settlement of the dispute under Article 287. In both legal and practical terms, the UNCLOS dispute settlement system is an effective legal instrument for nations of the world to manage and use the ocean sources peacefully and sustainably. Due to the dispute settlement mechanism regulated in the UNCLOS, disputes and conflicts among nations could be resolved peacefully, so that the threat or use of force to resolve these disputes, including disputes on maritime boundary, will be prevented and prohibited.

The primary purpose of this research is to clarify the substance and advantages of compulsory dispute settlement procedures entailing binding decisions under the provisions of the UNCLOS with the aim of providing legal advice to the government of the Socialist Republic of Vietnam in dispute settlement on interpretation and application of the UNCLOS in South China Sea between Vietnam and China.

This paper is composed of eight parts, including Introduction and Conclusion. Part two will overview conditions for compulsory procedures entailing binding decisions. The method of choosing compulsory procedures entailing binding decisions will be shown in Part three. Part four will clarifies the authority to dispute settlement of jurisdictional organizations under compulsory procedures entailing binding decisions. Part five will identifies limitations and exceptions of compulsory procedures entailing binding decisions. The applicable law and legal validity of dispute resolution under compulsory procedures entailing binding decisions will be indicated in Part six. Part seven will evaluate the applicability of compulsory dispute resolution entailing binding decisions to the case of Vietnam.

\section{Terms for A Dispute under the UNCLOS}

\section{A. Two Types of Disputes}

Following Article 288 of the UNCLOS, maritime disputes are divided into two types. One is the disputes concerning the interpretation or application of the UNCLOS and the other is any dispute concerning the interpretation or application of an 
international agreement related to the purposes of the UNCLOS. ${ }^{5}$ In this regard, a dispute concerning the interpretation or application of the UNCLOS will be a condition precedent for determining the jurisdiction of any court or tribunal referred to in Article 287 of the UNCLOS. To be a dispute, particularly, the parties must experience "a disagreement on a point of law or fact, policy in which a particular claim of one party is opposed or denied by the other or both sides made conflicting." ${ }^{6}$ In terms of the determination of the existence of the dispute, it was clearly clarified in the Barbados $v$. Trinidad and Tobago case by the arbitral tribunal constituted pursuant to Article 287, and in accordance with Annex VII, of the UNCLOS. In this case, Trinidad and Tobago objected to the authority of the arbitral tribunal, arguing that there was no specific and clear dispute arising between the parties. ${ }^{7}$ However, the tribunal argued:

the fact that the precise scope of the dispute had not been fully articulated or clearly depicted does not preclude the existence of a dispute, so long as the record indicates with reasonable clarity the scope of the legal differences between the Parties. The fact that in this particular case the Parties could not even agree upon the applicable legal rules shows that a fortiori they could not agree on any particular line which might follow from the application of appropriate rules. Accordingly, to insist upon a specific line having been tabled by each side in the negotiations would be unrealistic and formalistic. In the present case the record of the Parties' negotiations shows with sufficient clarity that their dispute covered the legal bases on which a delimitation line should be drawn in accordance with international law, and consequently the actual drawing of that line. ${ }^{8}$

Article 279 provides that parties "shall settle any dispute between them by peaceful means in accordance with Article 2, paragraph 3 of the Charter of the United Nations and, of this end, shall seek a solution by the means indicated in Article 33, paragraph 1, of the Charter." "Article 280 of the UNCLOS, however, does not prohibit states from

5 There are currently 15 international agreements related to the purposes of the UNCLOS. See R. Churchill, Dispute Settlement in the Law of the Sea: Survey for 2013, 30 InT'L J. MAR. \& COAST L. 34 (2013) (discussing the lack of jurisdiction in the Louisa case of the International Tribunal for the Law of the Sea and an order of provisional measures by this tribunal in the Arctic Sunrise case as well as the initiation of 10 new cases).

6 Nguyen Thi Lan Anh, Pratices of dispute settlement by arbitration under annex Vii of the 1982 United Nations convention on law of sea: Lesson for Vietnam, in Legal Issues Regarding The Incident of China's Placement of OiL Righai Haiyang Shiyou 981 in Vietnam's Eez and Cs 107-20 (Mai Hong Quy ed., 2015).

7 Maritime Boundary Delimitation (Barb. v. Trin. \& Tobago), PCA Case Repository 74 (Perm. Ct. Arb. 2006), https:// pcacases.com/web/sendAttach/1116.

$8 \quad I d .9198$.

9 U.N. Charter art. 33, ๆ 1. It stated: "the parties to any dispute, the continuance of which is likely to endanger the maintenance of international peace and security, shall, first of all, seek a solution by negotiation, enquiry, mediation, conciliation, arbitration, judicial settlement, resort to regional agencies or arrangements, or other peaceful means of 
joining a dispute settlement procedure concerning the interpretation or application of this Convention by chosen peaceful means. Article 281, paragraph 1 becomes effective if parties fail to reach an agreement by accepted means, and this agreement does not exclude any proceedings. ${ }^{10}$

Article 283 states that: "[w] hen a dispute arises between states parties concerning the interpretation or application of this Convention, the parties to the dispute shall proceed expeditiously to an exchange of views regarding its settlement by negotiation or other peaceful means." "The duration of negotiations can be flexible, but the parties must express a serious and goodwill attitude throughout the negotiations. ${ }^{12}$ If the dispute is still not resolved under Part XV, Section 1 of the UNCLOS, the parties may choose one of the compulsory procedures entailing binding decisions according to Part XV, Section 2 of the UNCLOS.

\section{B. The Choice of Dispute Settlement Mechanism}

Article 282 of the UNCLOS provides:

If the States Parties which are parties to a dispute concerning the interpretation or application of this Convention have agreed, through a general, regional or bilateral agreement or otherwise, that such dispute shall, at the request of any party to the dispute, be submitted to a procedure that entails a binding decision, that procedure shall apply in lieu of the procedures provided for in this Part, unless the parties to the dispute otherwise agree.

In this regard, the UNCLOS respects and prioritizes "obligations under general, regional, or bilateral agreements" over those under the Convention. Article 282 could cause substantial procedural obstacles to the effectiveness of Part XV of the UNCLOS. ${ }^{13}$ In the Southern Bluefin Tuna Cases, ${ }^{14}$ Australia and New Zealand stated

their own choice."

10 UNCLOS art. 281. It provides a procedure for the time when no settlement has been reached by the parties, stating the following: "1. If the States Parties which are parties to a dispute concerning the interpretation or application of this Convention have agreed to seek settlement of the dispute by a peaceful means of their own choice, the procedures provided for in this Part apply only where no settlement has been reached by recourse to such means and the agreement between the parties does not exclude any further procedure. 2. If the parties have also agreed on a time-limit, paragraph 1 applies only upon the expiration of that time-limit."

11 Id. art. 283, 11.

12 Supra note $7, \boldsymbol{\Upsilon} 292$.

13 D. Rothwell, Judicial Measures for Settlement of Disputes under UNCLOS, Legal Issues Relating to Awards of the Arbitral Tribunal Established under Annex VII of UNClOS 1982 Proc. (July. 23, 2016).

14 Southern Bluefin Tuna Cases (N.Z. v. Japan; Austl. v. Japan), Case No. 3\&4, Order of Aug. 27, 1999, ITLOS Rep. 
that Japan had violated the regulations on fishery conservation under the Convention for the Conservation of Southern Bluefin Tuna 1993 (CCSBT) and the UNCLOS, of which all three countries are members. ${ }^{15}$ These parties attempted to resolve the dispute through negotiation, but did not reach a final agreement in the end. Finally, Australia and New Zealand launched proceedings against Japan in accordance with Part XV of the UNCLOS. Responding to the request submitted by Australia and New Zealand, the ITLOS issued temporary measures to require Japan to immediately halt its unilateral fisheries until the problem could be resolved. ${ }^{16}$ The ITLOS, however, found that it lacked authority in this case, so that the proceeding could not continue. The ITLOS concluded that the dispute settlement through negotiation under the $\mathrm{CCSBT}^{17}$ is more advantageous than the mechanism under Part XV, Section 2 of the UNCLOS. ${ }^{18}$ According to the majority of the members of ITLOS, an agreement concerning dispute settlement related to the UNCLOS within the scope of Article 281 was created under the CSSBT. ${ }^{19}$

The choice of law in the MOX Plant case $\mathrm{e}^{20}$ was different from that in the Southern Bluefin Tuna case. The MOX Plant case arose between Ireland and the UK over the possibility of pollution in Irish waters stemming from nuclear fuel reprocessing in Cumbria. The scope of this dispute was not only limited to the UNCLOS, but also related to the Convention for the Protection of the Marine Environment of the NorthEast Atlantic (OSPAR) and the European legal system. After negotiations, finally, the ITLOS decided to follow the UNCLOS's dispute settlement system at Ireland's request and issued a temporary decision to resolve the dispute under Part XV of the

280, https://www.itlos.org/securedl/sdl-eyJ0eXAiOiJKV1QiLCJhbGciOiJIUzI1NiJ9.eyJpYXQiOjE2MTk1 MTE0MjcsImV4cCI6MTYxOTYwMTQyNiwidXNlciI6MCwiZ3JvdXBzIjpbMCwtMV0sImZpbGUiOiJmaWxlY WRtaW5cL210bG9zXC9kb2N1bWVudHNcL2Nhc2VzXC9jYXN1X25vXzNfNFwvcHVibGlzaGVkXC9DMzQtTy 0yN19hdWdfOTkucGRmIiwicGFnZSI6NjJ9.0_D1WYU9lfRHs1VpjiS71sjjSxXgEr9Y9h6U81ObX7c/C34-O-27_ aug_99.pdf.

15 Id. at 285-6.

16 Id. at 90. For details, see T. Stephens, International Courts and Environmental Protection 220-8 (2009).

17 CCSBT art.16, $\uparrow$ 1. It provides that the parties are obligated to "consult among themselves with a view to having the dispute resolved by negotiation, inquiry, mediation, conciliation, arbitration, judicial settlement or other peaceful means of their own choice."

18 Supra note 14 (Award on Jurisdiction and Admissibility, Aug. 4, 2000), at. 3, https://legal.un.org/riaa/cases/vol_ XXIII/1-57.pdf.

19 Id. at 55.

20 The MOX Plant Case (Ir. v. U.K.), Case No.10, Order of Dec. 3, 2001, ITLOS Rep. 95, https://www.itlos.org/ secured1/sdl-eyJ0eXAiOiJKV1QiLCJhbGciOiJIUzI1NiJ9.eyJpYXQiOjE2MTk1NzkyMTgsImV4cCI6MTYxOT Y2OTIxOCwidXNlciI6MCwiZ3JvdXBzIjpbMCwtMV0sImZpbGUiOiJmaWxlYWRtaW5cL210bG9zXC9kb2N1b WVudHNcL2Nhc2VzXC9jYXN1X25vXzEwXC9wdWJsaXNoZWRcL0MxMC1PLTNfZGVjXzAxLnBkZiIsInBh Z2UiOjEwMn0.SfWPLa4qV8goKlaKwWVOazpNjz71TGC9iKZywcc8Wa8/C10-O-3_dec_01.pdf. 


\section{UNCLOS. $^{21}$}

Both the Southern Bluefin Tuna case and the MOX Plant case have shown the difficulties in dealing with the disputes involving multiple dispute settlement systems for maritime affairs. However, the decision regarding the arbitral tribunal's jurisdiction in the Southern Bluefin Tuna case expressed a positive attitude for supporting the parties to continue to cooperate and reach an agreement of managing the fishing grounds if they are willing to collaborate and help with each other. ${ }^{22}$

\section{The Method of Choosing Compulsory Procedures Entailing Binding Decisions}

Article 287 of the UNCLOS has provided for a state the free right to choose the means for the settlement of disputes concerning the interpretation or application. When signing, ratifying, or acceding to the UNCLOS or at any time thereafter, through a written declaration, a state is therefore free to choose one or more means for the settlement of disputes such as the ICJ, the ITLOS, an arbitral tribunal, or a special arbitral tribunal. So far, 43 out of $168^{23}$ member states of the UNCLOS have declared their choice of the dispute settlement procedure in accordance with Article $287 .{ }^{24}$ As mentioned above, however, the compulsory dispute settlement procedures entailing binding decisions can be conducted if it meets three requirements as follows: (i) the parties to the dispute have cooperated and resolved the problem by peaceful means in accordance with Article 279; (ii) the parties to the dispute have negotiated and exchanged views under the provisions of Article 283, but the dispute is still not resolved; and (iii) the parties to the dispute are not bound by any dispute settlement measure or procedure provided for in a bilateral or multilateral treaty except for the UNCLOS.

A question may arise why arbitration is the default dispute settlement procedure

21 Id. at 111.

22 B. Mansfield, The Southern Bluefin Tuna Arbitration: Comments on Professor Barbara Kwiatkowska's Article, 16 InT'L J. MAR. \& COAST L. 361 (2001) (providing comments in response to a presentation by Professor Barbara Kwiatkowska of a version of her article at the SEAPOL Inter-Regional Conference on "Ocean Governance and Sustainable Development in the East and Southeast Asian Seas: Challenge in the New Millennium," Bangkok, Thailand, March 2123, 2001). See also N. Klein, Whales and Tuna: The Past and Future of Litigation between Australia and Japan, 21 Geo. EnvtL. L. Rev. 210-4 (2009) (discussing the ability of litigation option between Australia and Japan).

23 See United Nations Treaty Collection, https://treaties.un.org/Pages/ViewDetailsIII.aspx?src=TREATY\&mtdsg no $=$ XXI-6\&chapter $=21 \&$ Temp $=$ mtdsg $3 \&$ clang $=$ en.

24 See United Nations Ocean \& Laws of the Sea, https://www.un.org/Depts/los/settlement_of_disputes/choice_procedure.htm. 
under Article 287 of the UNCLOS. From the author's point of view, Annex VII provides the parties to the dispute with the flexibility to appoint ${ }^{25}$ and agree on the number and method of choosing arbitrators ${ }^{26}$ and to choose the dispute settlement procedure unless the parties to the dispute otherwise agree (meaning that arbitrators might set forth their own procedures). ${ }^{27}$ Moreover, in terms of costs, the court fees, including the arbitrator's remuneration, unless the arbitrators otherwise decide due to the special circumstances of the case, shall be paid equally by the parties to the dispute. ${ }^{28}$ An arbitral award is a final paramount and cannot be appealed unless the parties to the dispute agree in advance on appellate proceedings. Thus, this arbitral award will be complied with by the parties. ${ }^{29}$ Therefore, the UNCLOS has accepted jurisdiction to resolve the dispute by arbitration when all the parties or one party to the dispute have not declared a choice of dispute settlement procedures ${ }^{30}$ or have not accepted the same procedure for the settlement of the dispute. ${ }^{31}$

\section{The Authority of Dispute Settlement Body under Compulsory Procedures Entailing Binding Decisions}

In accordance with Article 287, the ICJ, the ITLOS, and arbitration are all given broad authority under Article 288 to resolve the following:

(i) Disputes concerning the interpretation or application of UNCLOS that are submitted to it in accordance with Part XV

(ii) Any dispute concerning the interpretation or application of an international agreement related to the purpose of UNCLOS, which is submitted to it in accordance with the agreement

A special arbitral tribunal constituted in accordance with Annex VIII, however, has only been authorized to settle such disputes as: (1) Fisheries; (2) Protection and preservation of the marine environment; (3) Marine scientific research; and (4)

26 Id. annex VII, art. 3.

27 Id. annex VII, art. 5.

28 Id. annex VII, art. 7.

29 Id. annex VII, art. 11.

30 Id. art. 287, ๆ 3 .

31 Id. art. $287, \uparrow 5$. 
International maritime, including pollution from vessels and by dumping. ${ }^{32}$

Thus, if the parties to the dispute choose the ICJ, the dispute will be resolved in accordance with the ICJ Statute. If the ITLOS is selected by the parties to the dispute, the dispute will be settled in accordance with Annex VI of the UNCLOS. If the parties to the dispute want arbitration or a special arbitral tribunal to solve the dispute, the provisions of Annex VII and Annex VIII will be applied, respectively. According to the author's survey, the ICJ used to be chosen by countries to resolve disputes concerning maritime delimitation. ${ }^{33}$

\section{Limitations and Exceptions of Compulsory Procedures Entailing Binding Decisions}

Article 297 of the UNCLOS provides: "Disputes concerning the interpretation or application of this Convention with regard to the exercise by a coastal State of its sovereign rights or jurisdiction provided for in this Convention shall be subject to the procedures provided for in section 2 in the following cases:"

(i) A coastal state has acted in contravention of the provisions of UNCLOS in regard to the freedoms and rights of navigation, overflight, or the laying of submarine cables and pipelines or in regard to other internationally lawful

32 Id. annex VIII, art. 1.

33 Resulted from the author's survey, up until March 2021, the ICJ had accepted and resolved 164 disputes, 24 cases $(14.63 \%)$ of which are related to territorial sovereignty disputes over land, borders, islands, archipelagos, and delimitation of the sea as well as disputes concerning the exploitation of marine resources. The following are these 24 cases: Obligation to Negotiate Access to the Pacific Ocean (Bolivia v. Chile); Maritime Delimitation in the Caribbean Sea and the Pacific Ocean (Costa Rica v. Nicaragua); Land Boundary in the Northern Part of Isla Portillos (Costa Rica v. Nicaragua); Maritime Dispute (Peru v. Chile); Territorial and Maritime Dispute (Nicaragua v. Colombia); Dispute regarding Navigational and Related Rights (Costa Rica v. Nicaragua); Maritime Delimitation in the Black Sea (Romania v. Ukraine); Sovereignty over Pedra Branca/Pulau Batu Puteh, Middle Rocks and South Ledge (Malaysia/ Singapore); Territorial and Maritime Dispute between Nicaragua and Honduras in the Caribbean Sea (Nicaragua v. Honduras); Land and Maritime Boundary between Cameroon and Nigeria (Cameroon v. Nigeria: Equatorial Guinea intervening); Maritime Delimitation and Territorial Questions between Qatar and Bahrain (Qatar v. Bahrain); Kasikili/ Sedudu Island (Botswana v. Namibia); Maritime Delimitation between Guinea-Bissau and Senegal (Guinea-Bissau v. Senegal); Maritime Delimitation in the Area between Greenland and Jan Mayen (Denmark v. Norway); Land, Island and Maritime Frontier Dispute (El Salvador/Honduras: Nicaragua intervening); Passage through the Great Belt (Finland v. Denmark); Continental Shelf (Libyan Arab Jamahiriya v. Malta); Delimitation of the Maritime Boundary in the Gulf of Maine Area (Canada v. U.S.); Continental Shelf (Tunisia v. Libyan Arab Jamahiriya); Aegean Sea Continental Shelf (Greece v. Turkey); North Sea Continental Shelf (Federal Republic of Germany v. Denmark); North Sea Continental Shelf (Federal Republic of Germany v. Netherlands); Miniquiers and Ecrehos (France v. U.K.); Corfu Channel (U.K. v. Albania). See ICJ, List of All Cases, https://www.icj-cij.org/en/list-of-all-cases. 
uses of the sea specified in Article 58 (i.e., the rights and obligations of other states in the exclusive economic zone).

(ii) A state, in exercising the aforementioned freedoms, rights, or uses, has acted in contravention of UNCLOS or laws or regulations adopted by the coastal state in conformity with UNCLOS and other rules of international law that are compatible with UNCLOS.

(iii) A coastal state has acted in contravention of specified international rules and standards for the protection and preservation of the marine environment that have been established by UNCLOS or through an authorized international organization or diplomatic conference in accordance with UNCLOS. ${ }^{34}$

Meanwhile, disputes concerning the interpretation or application of the provisions of the UNCLOS in regard to marine scientific research shall be settled based on arbitration or other procedures provided by Article 287 of the UNCLOS, excepting when the coastal state does not accept submission to such a settlement of any dispute arising out of the two following cases:

(i) A dispute arises from the exercise by the coastal state of a right or discretion in accordance with Article 246 (i.e., marine scientific research in the exclusive economic zone and continental shelf).

(ii) A dispute arises from a decision by the coastal state to order suspension or cessation of a research project in accordance with Article 253 (i.e., suspension or cessation of marine scientific research). ${ }^{35}$

Disputes concerning the interpretation or application of the provisions of the UNCLOS regarding fisheries shall be settled in accordance with other procedures pursuant to Article 287 of the UNCLOS, excepting when the coastal state does not accept submission to such a settlement of any dispute arising from the following four cases:

(i) A dispute relating to the sovereign rights of a coastal state with respect to the live resources in the exclusive economic zone or their exercise of those rights;

(ii) A dispute relating to discretionary powers of a coastal state for determining the allowable catch and the harvesting capacity of a coastal state;

(iii) A dispute relating to the allocation of surpluses of a coastal state to other states; and

(iv) A dispute relating to the terms and conditions established by laws and regulations of a coastal state on the conservation and management of biological resources 
in their exclusive economic zones. ${ }^{36}$

When signing, ratifying, or acceding to the UNCLOS or at any time thereafter, a state may, under Article 298 of the Convention, without prejudice to the obligations arising under Section 1 on general provisions of dispute settlement, declare in writing that it does not accept any one or more of the procedures provided for in Section 2 with respect to one or more of the following categories of disputes:

(i) Disputes concerning the interpretation or application of Article 15 (regarding territorial border delimitations), Article 74 (regarding exclusive economic zone delimitations), and Article 83 (regarding continental shelf delimitations) or those involving historic bays or titles; ${ }^{37}$

(ii) Disputes concerning the sea boundary delimitations settled by an agreement between the parties or disputes that must be settled in accordance with a bilateral or multilateral agreement binding upon those parties; ${ }^{38}$

(iii) Disputes concerning military activities, including military activities by government vessels and aircraft engaged in non-commercial service and disputes concerning law enforcement activities with regard to the exercise of sovereign rights or a jurisdiction excluded from the jurisdiction of a court or tribunal under Article 297, paragraph 2 or $3 ;^{39}$ and

(iv) Disputes with respect to which the Security Council of the United Nations is exercising its functions unless the Security Council decides to remove the matter from its agenda or calls upon the parties to settle it by the means provided for in UNCLOS. ${ }^{40}$

By flexibly applying these rules, the Philippines initiated a lawsuit against China in accordance with arbitration proceedings despite that China declared not to accept any of the procedures specified in Part XV, Section 2 of the UNCLOS for the four aforementioned types of disputes. Accordingly, under Point 40 of its Notification and

\footnotetext{
$I d$. art. 297, 93. a.

Id. art. 298.1.a.(i).

Id. art. 298.1.a.(iii).

39 Id. art. 298.1.b. In the South China Sea Arbitration case, the Tribunal has applied this regulation. Accordingly, the Tribunal affirmed: “... Additionally, Article 298 excludes disputes concerning military activities from the Tribunal's jurisdiction. The Tribunal considers that the specifics of China's activities on Mischief Reef and whether such activities are military in nature to be a matter best assessed in conjunction with the merits. The possible jurisdictional objections with respect to the dispute underlying Submission No. 12 therefore do not possess an exclusively preliminary character. Accordingly, the Tribunal reserves a decision on its jurisdiction with respect to the Philippines' Submission No. 12 for consideration in conjunction with the merits of the Philippines' claims." See The South China Sea Arbitration (Phil. v. China), PCA Repository 409 (Perm. Ct. Arb. 2016), https://pcacases.com/web/sendAttach/2086. Id. art. 298.1.c.
}

40 
Statement of Claim, the Philippines affirmed that:

... the Philippines's claims do not fall within China's Declaration of 25 August 2006, because they do not: concern the interpretation or application of Articles 15, 74 and 83 relating to sea boundary delimitations; involve historic bays or titles within the meaning of the relevant provisions of the Convention; concern military activities or law enforcement activities; or concern matters over which the Security Council is exercising functions assigned to it by the United Nations Charter. ${ }^{41}$

Under Article 299 of the UNCLOS, however, any dispute excluded from dispute settlement procedures pursuant to Article 297 or excepted by a declaration made by Article 298 may be submitted to compulsory procedures entailing binding decisions only by agreement of the parties to the dispute, and nothing in this section impairs the right of the parties to the dispute to agree to some other procedure for the settlement of said dispute.

\section{Applicable Law and Legal Validity of Dispute Resolution Decisions under Compulsory Procedures Entailing Binding Decisions}

Under Article 293, paragraph 2 of the UNCLOS, a court or tribunal provided for in Article 287 shall apply "this Convention and other rules of international law not incompatible with this Convention" to settle any dispute concerning the interpretation or application of the UNCLOS. However, those courts or tribunals having jurisdiction shall resolve a case under ex aequo et bono (fair) principle if the parties so agree. Moreover, pursuant to Article 288, paragraph 2, "a court or tribunal referred to in Article 287 shall also have jurisdiction over any dispute concerning the interpretation or application of an international agreement related to the purposes of this Convention which is submitted to it in accordance with the agreement." The applicable law of dispute settlement thus includes the provisions whose scope does not belong to the UNCLOS, even in the case that are not directly related to the law of

41 China's Declaration of August 25, 2006 affirmed that: "the Government of the People's Republic of China does not accept any of the procedures provided for in Section 2 of Part XV of the Convention with respect to all the categories of disputes referred to in paragraph 1 (a) (b) and (c) of Article 298 of the Convention." See United Nations, Treaties and International Agreements registered or filed and recorded with the Secretariat of the United Nations (Vol. 2384, 2006), https://reaties.un.org/doc/Publication/UNTS/Volume\%202384/v2384.pdf. 
the sea, such as the provisions of the Vienna Convention on the Law of Treaties 1969.

However, Article 293 is not considered the basis for expanding the scope of disputes under the jurisdiction of a court or tribunal referred to in Article 287 such as the disputes related to the law on international treaties or commercial law. "Other rules of international law" that are defined in Article 293 allow a court or tribunal to apply either the provisions of the secondary rules of international law, such as the Vienna Convention on the Law of Treaties, or the determination of the liability of the party that has acted against the international law on state responsibility. In some cases, the applicable law may be the primary rule of different fields of law. In the case of The Philippines vs. China, the arbitration referred to the provisions of the Convention on International Trade in Endangered Species of Wild Fauna and Flora (CITES) in interpreting Article $192^{42}$ and Article 194, paragraph $5^{43}$ of the UNCLOS to conclude that China had acted in contravention of the two provisions mentioned above when there was no measure to prevent its fishermen from catching the species on the banned lists issued by CITES. ${ }^{44}$ Previously, in the Chagos Marine Protected Area case, ${ }^{45}$ the arbitration also interpreted and applied the 1965 Lancaster House Agreement signed between the UK and Mauritius. ${ }^{46}$

Article 296 of the UNCLOS provides: "1. Any decision rendered by a court or tribunal having jurisdiction under this Section shall be final and shall be complied with by all the parties to the dispute. 2. Any such decision shall have no binding force except between the parties and in respect of that particular dispute." In this regard, legal validity is also recognized in Article 33 (Annex VI), ${ }^{47}$ Article 11 (Annex

42 UNCLOS art.192. It provides for the general obligation to protect and preserve the marine environment.

43 Id. art. 194, I 5. It states that "the measures taken in accordance with this Part shall include those necessary to protect and preserve rare or fragile ecosystems as well as the habitat of depleted, threatened or endangered species and other forms of marine life."

44 See PCA Case No 2013-19 in the matter of an arbitration before an arbitral tribunal constituted under Annex VII to the 1982 United Nations Convention on the Law of the Sea between the Republic of the Philippines and the People's Republic of China (2015), https://pcacases.com/web/sendAttach/2579.

45 Chagos Marine Protected Area Arbitration (Mauritius v. U.K.), PCA Repository (Perm. Ct. Arb. 2015), https://pca-cpa. org/en/cases/11.

46 PCA, In the matter of the Chagos marine protected area arbitration before An arbitral tribunal constituted under Annex VII of the United Nations Convention on the law of the sea between the Republic of Mauritius and the United Kingdom of Great Britain and Northern Ireland (2015), https://www.pcacases.com/pcadocs/MU-UK\%2020150318\%20Award. pdf.

47 UNCLOS annex VI, art. 33. It states: "1. The decision of the Tribunal is final and shall be complied with by all the parties to the dispute. 2. The decision shall have no binding force except between the parties in respect of that particular dispute. 3. In the event of dispute as to the meaning or scope of the decision, the Tribunal shall construe it upon the request of any party." 
VII), ${ }^{48}$ and Article 59 of the ICJ Statute. ${ }^{49}$ In case of any inconsistency between the parties concerning the interpretation or implementation of the award, either party has the right to request the tribunal to issue that award to resolve the problem. Moreover, if the parties to the dispute agree, disputes concerning the interpretation and implementation of the award may be submitted to any other court or tribunal referred to in Article 287 of the UNCLOS for settlement. ${ }^{50}$

Since the UNCLOS has entered into force, the courts and tribunals referred to in Part XV, Section 2 have been accepting and handling many cases related to maritime disputes. Among them, 11 cases have been accepted by the ICJ, mostly disputes concerning maritime borders and delimitation of the sea. ${ }^{51}$ The ITLOS settled 25 disputes, 11 cases of which were involved in crew members and the prompt release of vessels. ${ }^{52}$ Meanwhile, 12 cases related to the interpretation and application of the UNCLOS were accepted and resolved by arbitration. ${ }^{53}$ Special arbitration has no record in dispute settlement thus far. ${ }^{54}$

\section{The Applicability of Compulsory Dispute Resolution Entailing Binding Decisions to the Case of Vietnam}

The National Assembly of Vietnam issued a resolution approving the UNCLOS on June 23, 1994. However, in this Resolution and thus far, Vietnam has not issued any statement on the choice of compulsory procedures entailing binding decisions under

48 UNCLOS annex VII, art. 11. It provides for the finality of the award: "The award shall be final and without appeal, unless the parties to the dispute have agreed in advance to an appellate procedure. It shall be complied with by the parties to the dispute."

49 I.C.J. Statute art. 59. It states that: "the decision of the Court has no binding force except between the parties and in respect of that particular case." See also U.N. Charter art. 94, $\uparrow 2$. It provides for the compliance and enforcement of the ICJ's decisions: "2. If any party to a case fails to perform the obligations incumbent upon it under a judgment rendered by the Court, the other party may have recourse to the Security Council, which may, if it deems necessary, make recommendations or decide upon measures to be taken to give effect to the judgment."

50 UNCLOS annex VII, art. 12.

51 ICJ, List of All Cases, https://www.icj-cij.org/en/list-of-all-cases.

52 PCA, Cases, https://pca-cpa.org/en/cases.

53 For the list of Declarations of Choosing Arbitration constituted in accordance with Annex VII to resolve disputes concerning the interpretation and application of UNCLOS, see UN Division for Ocean Affairs \& the Law of the Sea, Declarations and Statements, https://www.un.org/Depts/los/convention_agreements/convention_declarations.htm. See also PCA Case Repository, https://www.pcacases.com/web/allcases.

54 UNCLOS annex VIII, art. 1. 
Article 287 of the UNCLOS. According to Point 4 of the Resolution, Vietnam only affirmed that it will "....settle disputes concerning territorial sovereignty as well as other disputes related to the South China Sea through peaceful means in the spirit of equality, mutual understanding and respect for international law, especially UNCLOS..." 55 Previously, Vietnam also affirmed in Point 7 of the Declaration on the Territorial Sea, Contiguous Zone, Exclusive Economic Zone, and Continental Shelf of 1977 that it "...will work together with other relevant countries, through negotiations on the basis of each other's independence and sovereignty, in accordance with international law and practice, to resolve the issues concerning maritime zones and continental shelf." ${ }^{56}$ Regarding disputes concerning sovereignty and delimitation of the sea in the South China Sea to which Vietnam is a related party, Vietnam will continue to maintain a consistent view of peaceful negotiation in dispute settlements which is the most preeminent solution for parties to settle disputes. It also excludes the possibility of third-party intervention, which could complicate the current situation in the South China Sea more complex. Conversely, with respect to disputes concerning the interpretation or application of the UNCLOS, Vietnam will actively conduct legal research to apply the compulsory dispute settlement procedures referred to in Article 287 of the UNCLOS.

In this regard, Vietnam first needs to declare arbitration as its prior choice of the dispute settlement procedures referred to in Article 287 for its flexibility and efficiency. The arbitration award issued in The Philippines vs. China on July 12, 2016, is considered a fair and objective determination under international law enhancing trust from the international community. Resolving disputes concerning the interpretation or application of the UNCLOS will be an important legal practice for Vietnam. For example, Vietnam and China currently have the following disputes concerning the interpretation and application of the UNCLOS:

(i) The dispute regarding China's U-Shaped Line Claim in the South China Sea issued on May 7, 2009. This claim is the clearest proof to affirm that China has misinterpreted and misapplied the UNCLOS and infringed upon Vietnam's sovereignty and sovereign rights in the South China Sea.

55 Resolution on the Approval of the 1982 UNCLOS < available only in Vietnamese>, (promulgated by National Assembly of the Socialist Republic of Vietnam, June 23, 1994), at 1, http://vbpl.vn/TW/Pages/vbpq-toanvan.aspx?Ite $\mathrm{mID}=10083 \&$ Keyword $=\mathrm{ph} \% \mathrm{C} 3 \% \mathrm{AA} \% 20 \mathrm{chu} \% \mathrm{E} 1 \% \mathrm{BA} \% \mathrm{~A} 9 \mathrm{n} \% 20 \mathrm{c} \% \mathrm{C} 3 \% \mathrm{~B} 4 \mathrm{ng} \% 20 \% \mathrm{C} 6 \% \mathrm{~B} 0 \% \mathrm{E} 1 \% \mathrm{BB} \% 9 \mathrm{Bc} \% 20$ lu $\%$ E1\%BA $\%$ ADt $\% 20$ bi $\%$ E1\%BB $\% 83$ n.

56 Statement of Vietnam Government on the Territorial Sea, the Contiguous Zone, the Exclusive Economic Zone and the Continental Shelf of 12 May 1977 <available only in Vietnamese>, (promulgated by Government of the Socialist Republic of Vietnam, May 12, 1977), https:/www.un.org/Depts/los/LEGISLATIONANDTREATIES/PDFFILES/ VNM_1977_Statement.pdf. 
(ii) The dispute regarding China's fishing ban in the South China Sea. This fishing ban runs annually from May 1 to August 16 and covers the area between China's Fujian and Guangdong Provinces, including Vietnam's Paracel Islands, parts of the Gulf of Tonkin, and the Scarborough Shoal. The ban has violated the legal fishing practices of Vietnamese fishermen on their traditional fishing grounds, including the waters around Vietnam's Paracel Islands.

(iii) The dispute regarding China's accretion and construction of artificial islands on seven reefs, including Johnson Reef (Gac Ma), Cuarteron Reef (Chau Vien), Fiery Cross Reef (Chu Thap), Gaven Reef (Ga Ven), Hughes Reef (Tu Nghia), Subi Reef (Xu Bi), and Mischief Reef (Vanh Khan), which China occupied in 1988 and 1995. This construction has seriously infringed upon Vietnam's sovereignty and jurisdictional rights under the provisions of Articles 56 and 60 of the UNCLOS.

(iv) The dispute regarding China's incursions into Vietnam's continental shelf and exclusive economic zone when China deployed an oil rig, the HYSY-981, into these areas from May 2, 2014, to July 15, 2014. This was the result of the incorrect interpretation and application of the UNCLOS by China, which encroached Vietnam's sovereignty and jurisdictional rights.

(v) The dispute regarding China's acts of threatening and interfering in cooperation on oil and gas exploitation in the South China Sea between Vietnam and the oil and gas corporations and companies of several countries. These acts infringe upon Vietnam's rights to its continental shelf under Article 77 of the UNCLOS. ${ }^{57}$

Pursuant to Part XV of the UNCLOS, Vietnam has sufficient legal basis to initiate a lawsuit against China according to arbitration procedures based on five arguments discussed below.

\section{A. These disputes are not excluded by China via China's Declaration of August 25, 2006.}

Although China does not admit any dispute and persistently assumes that the Chinese are exercising their inherent rights, core interests, and historic sovereignty in the South China Sea, it is clear that there is a dispute between Vietnam and China

57 UNCLOS art. 77. It states: "1. The coastal State exercises over the continental shelf sovereign rights for the purpose of exploring it and exploiting its natural resources. 2. The rights referred to in paragraph 1 are exclusive in the sense that if the coastal State does not explore the continental shelf or exploit its natural resources, no one may undertake these activities without the express consent of the coastal State. 3. The rights of the coastal State over the continental shelf do not depend on occupation, effective or notional, or on any express proclamation. 4. The natural resources referred to in this Part consist of the mineral and other non-living resources of the seabed and subsoil together with living organisms belonging to sedentary species, that is to say, organisms which, at the harvestable stage, either are immobile on or under the seabed or are unable to move except in constant physical contact with the seabed or the subsoil." 
because of China's misinterpretation and misapplication of the UNCLOS. This is the fundamental and decisive condition in both procedure and content for Vietnam to initiate a lawsuit against China according to arbitration procedures.

\section{B. Vietnam has actively applied political and diplomatic measures to resolve these disputes, while China has not cooperated.}

Article 281 of the UNCLOS provides:

1. If the states parties that are parties to a dispute concerning the interpretation or application of this Convention have agreed to seek settlement of the dispute by a peaceful means of their own choice, the procedures provided for in this part apply only where no settlement has been reached by recourse to such means, and the agreement between the parties does not exclude any further procedure.

2. If the parties have also agreed on a time-limit, paragraph 1 applies only upon the expiration of that time-limit.

Since the emergence of these disputes, Vietnam has negotiated and exchanged views with China, but China is still not willing to settle and does not have an agreement with Vietnam, making the dispute increasingly complex. It is an important basis on which Vietnam could apply the dispute settlement procedures referred to in Article 287.

\section{Vietnam and China are not bound by any specific dispute settlement obligations in bilateral or multilateral international treaties.}

Thus far, Vietnam and China have not been bound by any specific dispute settlement agreements bilaterally and regionally under Article 282 of the UNCLOS. In fact, the two countries are only bound by the 2002 Declaration on the Conduct of Parties in the South China Sea (DOC), the 1976 Treaty of Amity and Cooperation in Southeast Asia (TAC), the 1993 Agreement on Basic Principles for the Settlement of Border Territory Issues between the Socialist Republic of Vietnam and the People's Republic of China, and a 2011 agreement on basic principles guiding the settlement of sea-related issues. However, these documents only provide general provisions on the settlement of disputes by peaceful means under international law and do not mention any specific dispute settlement procedures. In The Philippines vs. China case, the arbitration indicated that the "DOC is not an international treaty and not binding on measures to 
settle disputes between signatory countries. ${ }^{, 58}$

\section{Arbitration is the default dispute settlement procedure.}

Neither Vietnam nor China has made any statement on the choice of dispute settlement procedures related to the interpretation or application of the UNCLOS under Article 287. Therefore, according to Article 287, paragraph 3, Vietnam and China can automatically choose arbitration to settle disputes concerning the interpretation and application of the UNCLOS.

\section{E. The scope and content of a lawsuit initiated by Vietnam will not violate the limitations and exceptions referred to in Articles 297 and 298 of the UNCLOS.}

According to Article 297 of the UNCLOS, the scope and content of the lawsuit initiated by Vietnam, if any, will perfectly meet the demands because the aforementioned disputes concern the interpretation and application of the UNCLOS. Meanwhile, the content of Vietnam's lawsuit will not violate Article 298 of the UNCLOS on the exceptions to the applicability of Section 2 or China's Declaration of August 25, 2006, referring jurisdictional bodies that China claimed to reserve.

\section{Conclusion}

In both theory and practice, the regulations on compulsory dispute settlement entailing binding decisions under Part XV of the UNCLOS have provided international legal basis for countries to choose and apply for the dispute resolution on the interpretation or application of the UNCLOS. According to Article 287, the settlement of disputes by an arbitral tribunal constituted in accordance with Annex VII is a default procedure in case either one or both parties to a dispute are not covered by a declaration in force, or the parties to a dispute have not accepted the same procedure for the settlement of the dispute. Based on legal practice, this paper has clarified and analysed legal issues related to compulsory dispute settlement entailing binding decisions, including the conditions of application, the choosing method, the authority of dispute settlement body, limitations and exceptions, the applicable law and legal validity, in order to

58 Supra note 39, at. 61. 
better understand the nature of these procedures. Moreover, by referring to recent disputes on the interpretation or application of the UNCLOS between Vietnam and other countries in the region, the author has provided further evidence and legal arguments to consult with the Government of Vietnam in studying, choosing, and applying these procedures.

From the author's view, the rule of law should be respected by the civilized countries as a whole. Therefore, the proactive and flexible application of international dispute settlement mechanisms, including compulsory procedures entailing binding decisions as provided for in Article 287, should be applied to protecting legitimate sovereign rights and jurisdiction over the waters under the UNCLOS. This is a starting point of building peaceful, progressive, and civilized order of ocean. 
